\title{
Bolsa Família, time spent in school and students' motivations
}

\author{
Marcelo Neri 12 \\ Manuel Camillo Osorio ${ }^{1}$ \\ ${ }^{1}$ Fundação Getulio Vargas / Centro de Políticas Sociais (FGV Social), Rio de Janeiro / RJ - Brazil \\ ${ }^{2}$ Fundação Getulio Vargas / Escola Brasileira de Economia e Finanças (FGV EPGE), Rio de Janeiro / RJ - Brazil
}

This article studies the impact of the Bolsa Família Program (BFP) on time spent in school, its components (enrollment, attendance, and school journey), and on the reasons students dropout or show low-attendance. The research uses data from the National Household Sample Survey (PNAD) for the years 2004 and 2006. During this period, the BFP coverage expanded by $67 \%$ enabling to test the dosage-effects of the program. The tests could not refute the hypothesis related to the impact of the BFP on time spent in school, and any of its components. Another identification strategy used shows that teenagers marginally eligible to BFP were $62 \%$ more likely to be enrolled at school, $8 \%$ more likely to comply with the attendance conditionality, and 6\% more likely to study more than 4 hours per day. Finally, tests on the alleged reasons leading beneficiaries to fail in complying with the BFP conditions could not reject the existence of an effect of current income relief related to the program.

Keywords: education; school journey; CCTs; Bolsa Família; poverty.

\section{Bolsa Família, tempo na escola e motivações estudantis}

Esta pesquisa analisou o impacto do Programa Bolsa Família (PBF) no tempo na escola, em seus componentes (matrícula, presença e jornada) e nas motivações relacionadas a partir dos suplementos especiais da Pesquisa Nacional por Amostra de Domicílios (PNAD) de 2004 e 2006. A expansão de 67\% na cobertura do PBF no período permite testar efeitos-dosagem desse programa. Não se rejeitaram as hipóteses de impacto do PBF no tempo na escola e em seus componentes. Outra estratégia de identificação revela que os jovens marginalmente elegíveis em idade ao PBF apresentaram chances 62\%, 8\% e 6\% maiores de frequentar a escola, cumprir a presença mínima e estudar mais do que 4 horas por dia, respectivamente, do que os quase elegíveis. Por fim, testes sobre as motivações alegadas para transgredir as condicionalidades escolares não descartam um efeito de alívio de renda corrente proporcionado pelo PBF.

Palavras-chave: educação; jornada escolar; transferências de renda; Bolsa Família; pobreza.

\section{Bolsa Familia, tiempo en la escuela y motivaciones de los estudiantes}

Estudiamos el impacto del Programa Bolsa Familia (PBF) sobre el tiempo en la escuela, sus componentes (matrícula, presencia y jornada) y motivaciones relacionadas a partir de los suplementos especiales de la Encuesta Nacional de Hogares por Muestreo (PNAD) de 2004 y 2006. La expansión del 67\% del PBF en el período permite probar efectos-dosificación del programa. No rechazamos la hipótesis de impacto del PBF sobre el tiempo en la escuela y sus componentes. Otra estrategia de identificación muestra que los jóvenes marginalmente elegibles en edad al PBF presentaron chances $62 \%, 8 \%$ y $6 \%$ mayores de asistir a la escuela, cumplir con la presencia mínima y estudiar más de $4 \mathrm{~h}$ /día, respectivamente, que los casi elegibles. Evidencias acerca de las motivaciones para transgredir las condicionalidades no descartan un efecto de alivio de ingresos proporcionado por el PBF.

Palabras clave: educación; jornada escolar; transferencia monetaria condicionada; Bolsa Família; pobreza. 


\section{INTRODUCTION}

This article studies children's time in school, here understood as the average daily hours spent by each potential student inside the school. Data from the 2004 and 2006 national household survey (PNAD - Pesquisa Nacional de Amostra por Domicílio) are used in this research project since they represent a valuable dataset on education and government's social policies - themes which were not explored in details by PNAD after these two years.

We propose an indicator to assess the length of the school journey that students are daily subjected in school, also incorporating their attendance inside the classroom and the zero time spent in school by the potential students that are not enrolled (Neri, 2009b). By considering as elements of supply or demand the reasons given by the students for their short permanence in school - such as why they did not attend classes or dropped out, we offer an economic interpretation of the motives related to their time in school (Neri, 2009a).

The article's main contribution is to study the impact of the biggest conditional cash transfer in Brazil - the Bolsa Família programme (Family Grant; BFP henceforth) - on the time in school, its components (enrolment, attendance and school journey) and the motives related to the students' short permanence in school.

The programme's coverage expanded 67\% between 2004 and 2006. Two identification hypothesis underpin the empirical evaluation and are based on the eligibility criteria for the BFP's educational variable benefit that is targeted to the children. The first is linked to the family's economic situation, assessed by the per capita household income, while the second is related to the household's composition, in particular the cut-off age for receiving this benefit.

We use the differences-in-differences methodology in binomial and multinomial models controlled by the potential students' sociodemographic characteristics. The time in school is assessed through its three components: enrolment, attendance and school journey, besides an indicator that combines their interaction. Then, the main questions to be addressed are the following:

- How the time in school changed between 2004 and 2006 regarding the BFP's educational conditionalities?

- Which component gave the biggest contribution to these changes?

- What were the alleged motives to dropout or not attend classes?

We investigate the causes of the time spent in school through two complementary identification hypothesis. First, we test the impact of the programme on the three components of the time in school and test the hypothesis of income alleviation for the eligible families, incorporating to the analysis the motives to dropout and the non-compliance to the minimum required attendance in the classroom (BFP's demands the beneficiary to attend $85 \%$ of total classes). Then, we test the effects in the components separately and in their combined indicator. Finally, we estimate the inequality in the time in school distribution and in each of its components given the conditionalities' targeted population.

Besides this introduction, the article is structured in other four sections. In the next section the data and methodology are presented. The following two sections present the results and then a conclusion ends the article. 


\section{DATA AND METHODOLOGY}

\subsection{PNAD's special supplements}

The national household survey (PNAD) objective is to collect information on the socio-economic characteristics of the Brazilian society. In order to do that, it maintains a permanent questionnaire with general information on the population, such as labour status, education, income and housing. Moreover, the survey offers a special supplement, presenting complementary information by focusing on health, marital status, social policies, etc.

In this article we use the special supplements on education and social policies present in PNADs 2004 and 2006. The questionnaire was answered by the potential students themselves or a relative who was at home in the moment of the interview. These supplements were selected for three main reasons: i) from 2004 onwards, PNAD incorporated the rural area in the North region to its survey, thus finally covering the entire country territory; ii) between 2004 and 2006 the BFP's coverage expanded 67\%, going from 6.5 million families covered to almost 11 million; iii) education and social policies were not part of the special supplement in the following years.

\subsection{Bolsa Família Programme (Family Grant or BFP)}

The BFP is a conditional cash transfer (CCT) created by the federal government in 2003 that is targeted at the Brazilians living below the poverty line.

In the last years, different evaluations revealed the positive impacts of CCTs on poverty (Hanlon, Barrientos, \& Hulme, 2010) and on subjective wellbeing and social bonding (Molyneux, Jones, \& Samuels, 2016). Regarding the BFP - a pillar for the historical period of inclusive growth (Kakwani, Neri, \& Son, 2010) observed in the country in the turning of the 21st century, evaluations of the programme show positive effects on different dimensions, such as poverty (Campello, 2013; Paiva, Falcão \& Bertholo, 2013; Souza \& Osorio, 2013; Neri, 2017; Sawyer, 2007), labour market (Oliveira \& Soares, 2013; Rêgo \& Pinzani, 2013; Pedrozo, 2010) and education (Craveiro \& Ximenes, 2013; Cereno, Silva \& Proença, 2013; Silveira, Campolina \& Horn, 2013; Cardoso \& Souza, 2004).

Between 2004 and 2006, two groups were considered eligible in income terms for the programme. The first was made of families with per capita monthly income between $R \$ 50,01$ and $\mathrm{R} \$ 100$ - which is the poverty line stipulated for the programme, and with pregnant women or children between 0 and 15 years old. This group received R\$ 15 benefits in exchange of meeting prespecified conditionalities, with the limit being $\mathrm{R} \$ 45$. Regarding the educational conditionalities attached to the benefit, the family were required to not only enrol their children between 6 and 15 years old in the school but also make them attend at least $85 \%$ of the classes. The second group, in turn, was made of families below the extreme poverty line - per capita monthly income below or equal to $\mathrm{R} \$ 50$. These families received a $\mathrm{R} \$ 50$ benefit independently of the household composition, also being eligible to the variable benefit in case of meeting the 
prespecified conditionalities imposed on their children. Consequently, the maximum benefit for this group is $\mathrm{R} \$ 95 .^{1}$

In order to estimate the BFP's impact on children's time in school, we compare the values reported for per capita income - net of transfers from social policies - to the BFP's eligibility income lines in 2004 and 2006. Therefore, it is possible to pin down two comparable points in time for either the eligible or ineligible group of people, a fundamental condition for the differences-in-differences methodology to be successful.

The regressions are based on two identifications hypothesis based on the eligibility criteria for the BFP's variable benefit. The first is linked to the family's income, assessed by the per capita household income, while the second is linked to the family's composition, in particular a discontinuity in the cut-off age that defines children's eligibility for receiving the benefit. Both interact in order to test dosage-effects of the program. Thereby, in the first hypothesis we test the impacts on the income eligible population in relation to the ineligible; then we focus the analysis exclusively on the income eligible group to test the effects observed from the discontinuity on the maximum age criterion for receiving the benefit.

\subsection{Income Hypothesis}

By assessing individuals with the same socioeconomic and demographic characteristics, differentiated only by their position in relation to the income eligibility line in 2004 and 2006 - net of social transfers, we suppose that the non-observable characteristics are similar between the groups so that any statistically significant impact on the odds ratio for the time in school of the eligible group in relation to the ineligible group, between both years, are better explained as the effect of the CCT programme in the period.

\subsection{Age Hypothesis}

The variable benefit is only suspended in the beginning of the following calendar year after the individual completed 16 years of age. Therefore, the identification strategy is focused on the families whose children completed 16 years in the first two months of the year in relation to the families whose children achieved the same age in the last two months of the previous year (Barbosa \& Courseuil, 2013). Since we are only comparing families eligible in income terms with children that have just completed 16 years, also with similar socioeconomic and demographic characteristics, the identification hypothesis is that the children's age is randomly assigned and independent from the families' control, thereby, any statistically significant difference in the odds ratio for the time in school of the eligible group, in relation to the non-eligible, according to this age eligibility rule, is better explained as the effect of the CCT programme in the period.

\footnotetext{
${ }^{1}$ Nowadays there is no maximum benefit level and the families that are still below the extreme poverty line (today in R $\$ 89$ ), in per capita terms, after receiving all available benefits, now have their income lifted up to the extreme poverty line. (Programa Brasil Sem Miséria - Brazil Without Extreme Poverty programme).
} 


\subsection{Empirical Model}

The multivariate analysis is structured in three main dependent variables, namely, if the potential student (i) is enrolled in school; (ii) meet the attendance conditionalities; and (iii) is limited by the legal minimum of four hours per day in school. Combining the PNAD's microdata for 2004 and 2006, these three components are analysed through three different binomial logistic regression models: (a) with controls but without interactive variables; (b) with controls and interactive variables; (c) only interactive variables. Then, the changes in the time in school are estimated using an ordered multinomial model according to the indicator that combines the three components.

The binomial models were estimated with and without interactive variables in order to assess static and dynamic effects, testing the hypothesis of dosage-effects through interactive variables in time. We also test as dependent variables the reasons given by the students, for instance the demand or supply reasons given for not being enrolled in school, in order to explore the hypothesis of income relief for the eligible group due to the CCT programme.

In the binomial models the dependent variable is a dummy, a variable that can assume only one out of two possible values, "yes" or "no". A dummy for school enrolment, for example, presents either the value " 1 " for the enrolled student or " 0 " otherwise. In the model proposed, the dependent variable is explained by vectors containing the student's socioeconomic characteristics (sex, age, colour, household income and schooling) and spatial information (Unit of the Federation he/she lives, census region, and if he/she lives in the city in which he/she was born). Moreover, dummies are also included to the model to describe if he/she is eligible or not to the BFP (according to income or age criteria) and incorporate the effect of time variation between 2004 and 2006. It is worth noting that we consider all answers given in PNAD, not discriminating if they were given by the potential student in person or by a relative who was present in the household during the interview since this discrimination could bias the results. We only focus on the interactive results using the differencesin-differences methodology. The following equations exemplify the methodology:

$\mathrm{Y}=\mathrm{g}_{0}+\mathrm{g}_{1} * \mathrm{~d}_{2}+\mathrm{g}_{2} * \mathrm{~d}_{\mathrm{B}}+\mathrm{g}_{3} * \mathrm{~d}_{2} * \mathrm{~d}_{\mathrm{B}}+$ controls $\mathrm{g}_{3}=\left(\mathrm{y}_{2, \mathrm{~b}}-\mathrm{y}_{2, \mathrm{a}}\right)-\left(\mathrm{y}_{1, \mathrm{~b}}-\mathrm{y}_{1, \mathrm{a}}\right)=$ differences-in-differences impact

Where Y represents the variable of interest (for example, school enrolment), the 'g's are the four coefficients of the equation $\left(g_{0}, g_{1}, g_{2}\right.$ and $\left.g_{3}\right)$ and the 'd's indicate dummies. The numbers or uppercase letters following a dummy indicate the sample period and the group of the population, respectively. For the income hypothesis, for instance, we have ' 1 ' for 'year 2004' and '2' for 'year 2006', besides 'A' for the control group 'ineligible to BFP' and 'B' to treatment group 'eligible to BFP'.

Consequently, ' $\mathrm{g}_{3}$ ' assesses the impact of the differences-in-differences methodology and is only different from zero for the individual who is a member of the treatment group after the BFP's expansion occurred, thus an individual for both groups ' $\mathrm{B}$ ' and ' 2 '.

For the effects in school journey - which is not transformed into a dummy as instinctively as enrolment and attendance, we use a binomial logistic regression model in which the dependent variable is equal to ' 1 ' when the school journey is equal to the legal minimum of four hours or ' 0 ' in case of more hours of teaching are being offered in school. 


\subsection{Inequality}

Finally, we assess how educational inequality changed for the target population between 6 and 15 years old and the 16 years old group which is subject to the age eligibility rule during this period, comparing the results to the inequality reduction phenomenon observed concomitantly in Brazil at a nation scale. In order to do that, we use the Gini Coefficient to evaluate the distribution in the time in school and its three components between 2004 and 2006.

An appendix with all regressions and a more detailed bibliography is available online: https:// www.cps.fgv.br/cps/bd/docs/Apendice_BolsaFamilia-TempoNaEscola-MotivacoesEducacionais.pdf.

\section{COUNTING THE TIME IN SCHOOL}

First, we propose an indicator that resumes the time in school of each potential student according to the average daily hours he/she spent inside the school. Going beyond the investigation if the potential student is enrolled or not in school, the proposed time in school indicator also involves the days in which the student attended classes and the length of the school journey. By using this indicator we want to not only quantify the time dedicated to studying for each of the two groups of interest, but also to investigate where the potential student is gaining (or losing) more time in school between 2004 and 2006. Moreover, we discuss the subjective determinants linked to a short permanence in school, analysing the different reasons given for leaving school or missing classes as elements of supply and demand related to time in school. To sum up, the section's objective is to offer an initial economic interpretation for the length of the time in school as a motivation for the proposed empirical exercises. The main questions to be addressed are:

- How time in school changed between 2004 and 2006?

- What was the contribution of each component for these changes?

- Was it already possible to suggest CCTs' impacts on time in school in 2004, for example through Bolsa Escola (School Grant)?

- Can the collected data be used as a motivation for a multivariate assessment on the Bolsa Família's impact on time in school and the related motives to a short permanence in school for the eligible groups during the programme's expansion period?

\subsection{Concept and indicator}

The time in school indicator is an outcome of the School Permanence Index (SPI), which is the product of the enrolment index, the attendance index and the school journey indexes. All indexes and the time in school indicator are elaborated using the questions on education present in the PNAD's questionnaire.

The Enrolment Index (EI) measures the proportion of people enrolled in school. Therefore, it represents the inverse of the dropout ratio and it is estimated based on the a question in PNAD's questionnaire which asks if the respondent is enrolled or not in school.

The Attendance Index (AI) measures the proportion of school days that were in fact enjoyed by the enrolled students. Thereby, it represents the inverse of the proportion of days in which the student 
did not go to school. PNAD's special supplement has two questions on the number of missing school days: one questioning if the student did not attend school at least once in the last two months and, in case of an affirmative answer, a second question presenting five possible responses, going from 1 to 5 missed classes in the first option, to over 20 missed classes in the fifth.

The School Journey Index (SJI) presents the length of the daily school journey in relation to a school journey of reference (SJR) equal to five daily hours. ${ }^{2}$ This is a supply variable decided by school directors and policy makers. Studies reveal that educational outcomes, such as school marks, are positively correlated to the school journey but with decreasing returns (Menezes \& Oliveira 2008; Neri, 2009b).

In order to obtain a more intuitive result to interpret the numbers we use the product of the three indexes and the SJR, which is the time in school indicator. Consequently, the time in school indicator measures how many daily hours, in average, a potential student spends in school based on its three components: enrolment, attendance and school journey.

\section{FIGURE 1 SCHEME PRESENTING THE TIME IN SCHOOL INDICATOR}

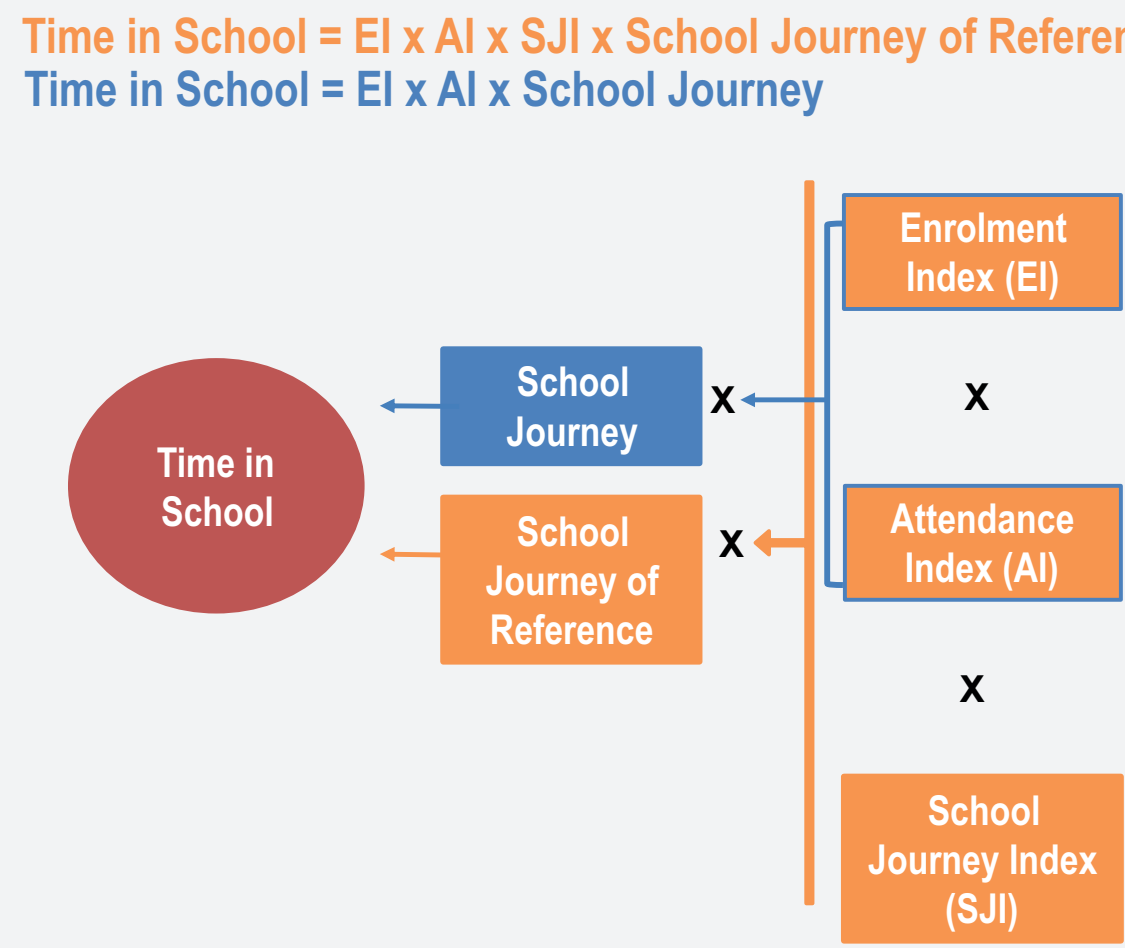

Source: Elaborated by the authors.

\footnotetext{
${ }^{2}$ The values used to estimate the school journey are (i) four hours, the minimum according to the law that regulates education in Brazil (Law no 9394/1996); (ii) five hours and (iii) seven hours. These values are compared in relation to an ideal school journey of five hours, which was decided after reviewing the literature that is present in the bibliography.
} 


\subsection{Time in school for the population between 6 and 15 years old}

The emphasis lies on the changes in the time in school for the population subjected to the BFP's educational conditionalities. Thus, the analysis is restricted to the children between 6 and 15 years old, using the differences in the age eligibility criteria for the group with 16 years old who is also income eligible in order to confirm the results obtained.

Table 1 reveals that, between 2004 and 2006, time in school increased not only for the whole population of children between 6 and 15 years of age, but increased the most for the 20\% poorest and for the eligible to CCT programmes within the bottom quintile. For the whole population there were balanced gains in all components, with a bigger increase in the attendance index. It is worth noting that, in 2004, dropout ratio was already low for this age group (around 5\%), therefore, representing almost an universal coverage. Since the enrolment index had the lowest gains in this period, a substantial share of the 3.3\% increase in time in school was due to gains in attendance and school journey. Then, if the enrolment index was close to universal coverage in this period for this age group, was the BFP's educational conditionalities focusing on an inexistent problem? After assessing the statistics for the children between 6 and 15 years old eligible to the variable benefit it is clear that they have significantly fewer educational opportunities, especially when looking to the enrolment and school journey indexes.

TABLE 1 TIME IN SCHOOL BETWEEN 2004 AND 2006

\begin{tabular}{|c|c|c|c|c|c|c|}
\hline \multicolumn{7}{|c|}{6 to 15 years old - Educational Conditionalities' Target Population } \\
\hline Group & Year & Time in School & $\begin{array}{l}\text { School } \\
\text { Permanence } \\
\text { Index }\end{array}$ & $\begin{array}{l}\text { Enrolment } \\
\text { Index }\end{array}$ & $\begin{array}{l}\text { Attendance } \\
\text { Index }\end{array}$ & $\begin{array}{c}\text { School } \\
\text { Journey Index }\end{array}$ \\
\hline \multirow{2}{*}{ Total Population } & 2004 & 3.99 & 0.80 & 0.95 & 0.94 & 0.89 \\
\hline & 2006 & 4.12 & 0.82 & 0.96 & 0.96 & 0.90 \\
\hline \multirow{2}{*}{$20 \%$ Poorest } & 2004 & 3.73 & 0.75 & 0.92 & 0.93 & 0.86 \\
\hline & 2006 & 3.91 & 0.78 & 0.94 & 0.95 & 0.87 \\
\hline \multirow{2}{*}{ Eligible } & 2004 & 3.79 & 0.76 & 0.93 & 0.94 & 0.87 \\
\hline & 2006 & 3.92 & 0.78 & 0.94 & 0.95 & 0.87 \\
\hline \multicolumn{7}{|c|}{ Variation between 2004 and 2006 (\%) } \\
\hline Total Population & & $3.30 \%$ & $3.30 \%$ & $0.91 \%$ & $1.25 \%$ & $1.11 \%$ \\
\hline $20 \%$ Poorest & & $4.81 \%$ & $4.81 \%$ & $2.00 \%$ & $1.81 \%$ & $0.93 \%$ \\
\hline Eligible & & $3.65 \%$ & $3.65 \%$ & $1.07 \%$ & $1.85 \%$ & $0.70 \%$ \\
\hline
\end{tabular}

Source: Elaborated by the authors. 
The multiplicative structure of the SPI allow us to disentangle its rate of variation into a logarithmic approximation of the sum of each component's rate of variation. ${ }^{3}$ Then, table 1 also reveal that $80 \%$ of the change in the time in school of children between 6 and 15 years old occurred due to gains in school enrolment and attendance, both components directly affected by the BFP's educational conditionalities. Thereby, the programme is not wrong in focusing on this group given the educational discrepancies observed for the population eligible for the variable benefit.

It is worth noting that the time in school for the $20 \%$ poorest increased even more substantially in this period. Once this group encompass the eligible and non-eligible in income terms for CCTs programmes, it is important to run statistical tests in order to confirm the hypothesis of the programme's impact on its target population.

Since the Bolsa Escola programme (School Grant), and later the BFP, were designed with the goal of relieving, in the short-run, a lack of income, we investigate if the data suggest an income relief for the eligible group in relation to the peers in the first income quintile. However, the motives given to dropout are not clear regarding this hypothesis of poverty alleviation linked to CCTs programmes' benefits. Whereas in 2004 the eligible group gave motives to not go to school related to demand and demand $1,{ }^{4}$ in average, $11 \%$ lower than the group in the first quintile, in 2006 the ratio was apparently inverted since the eligible group dropped out $9 \%$ more than the poorest quintile group due to motives linked to a lack of income.

\subsection{The 16 years-old teenagers and the maximum age eligibility rule}

Before engaging with the multivariate analysis in order to test the existence of CCTs' impact on the time in school of the population subjected to meet the programmes' conditionalities, we decided to first investigate in depth the PNAD's data for the income eligible 16 years-old teenagers in 2004 and 2006. The idea is to observe a corner solution, trying to assess the existence of an impact when the teenager stops receiving the benefit after completing 16 years of age, given the maximum age eligibility rule that disproportionately favours the teenagers that have turned 16 years old in the beginning of the year. If the impact is confirmed, we try to estimate the moment in which the differences for the 16 years old population started to become observable in the data, once the Bolsa Escola programme was already in place in 2004, even if in a smaller scale in terms of population covered.

By assessing the aggregated data for the population born between 1987/88 in 2004 and 1989/90 in 2006 divided in periods of two months, we observe substantial differences for the teenagers born in the last two months of 1987 and 1989 in relation to the people born in the first two months of 1988 and 1990. The turning of the calendar year shows a discontinuity between, on the one hand, the group of teenagers that turned 16 years in the last two months of 2003 and 2005 - thus supposedly ineligible to CCTs programmes in the following calendar year; and, on the other hand, the group of teenagers that were born in January and February of 1988 and 1990, so, in theory, remained eligible for the School Grant and the BFP in 2004 and 2006, respectively. Figure 2 shows the changes in the time in school for the four months most exposed to the age eligibility rule, emphasising the differences for

${ }^{3} T X, I P E=T X, I M+T X, I P+T X, I J$

where Tx represents rate of variation of each indicator.

${ }^{4}$ We constructed a proxy for the families' income needs denominated "demand1", which is equal to the sum of the following main motives given to abandon school: a) help in household activities; b) find a job; c) lack of income; and d) parents asked the child to work. 
teenagers that started 2004 and 2006 eligible for CCTs benefit because they completed 16 years in the first two months of the calendar year in relation to the teenagers that started those years not eligible because they completed 16 years of age in the last two months of 2003 and 2005.

\section{FIGURE 2 CHANGES FOR INCOME ELIGIBLE TEENAGERS WHO COMPLETED 16 YEARS IN THE FIRST TWO MONTHS OF THE YEAR IN RELATION TO THOSE WHO COMPLETED 16 YEARS IN THE LAST TWO MONTHS OF THE PREVIOUS YEAR}

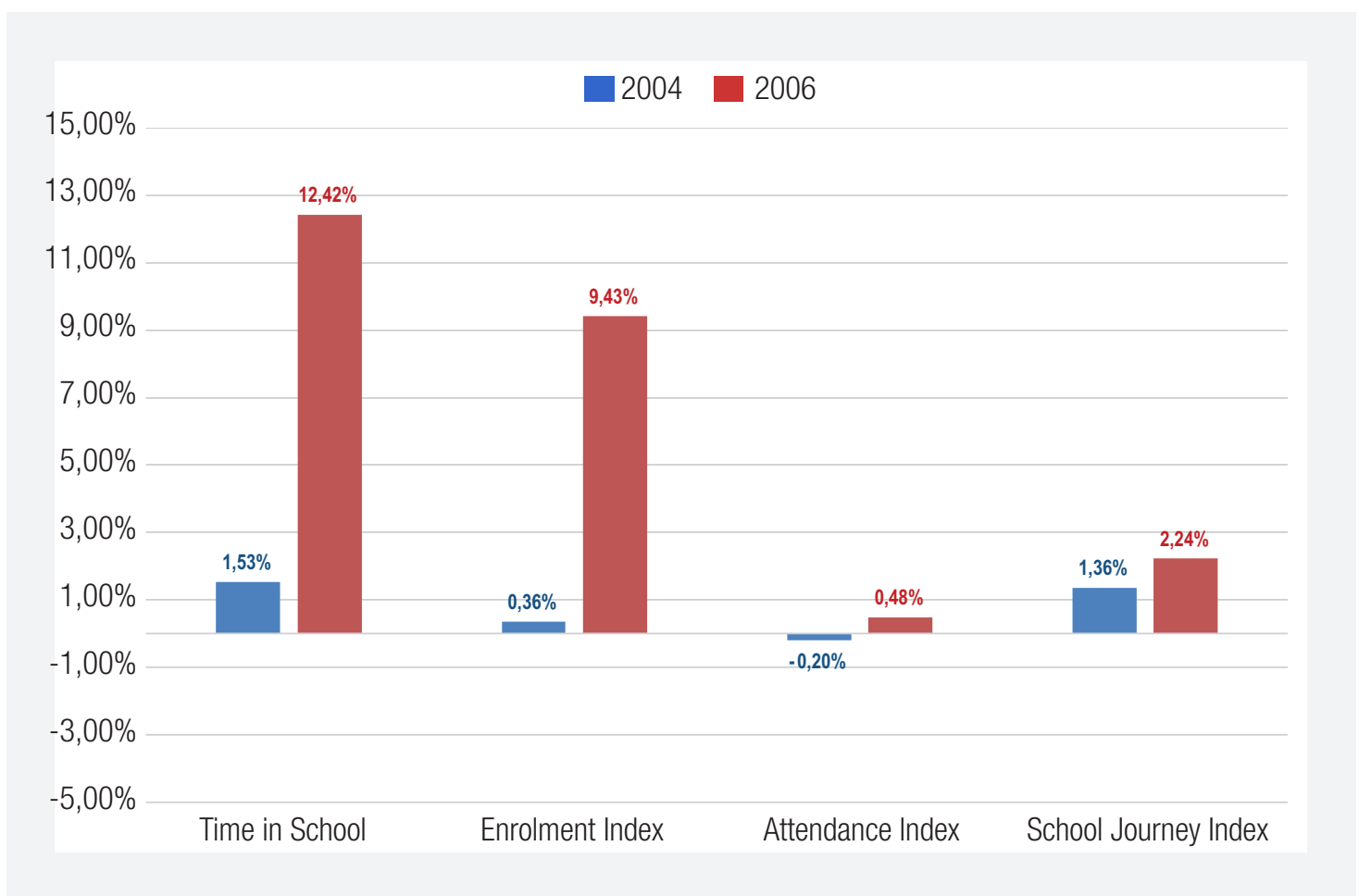

Source: Elaborated by the authors.

It is possible to observe a positive change in all indicators for the age eligible group of teenagers in relation to those not eligible, in 2004 and 2006, being the attendance index the only exception.

Figure 2, however, does not suggest a positive effect of CCTs on the time in the school in $2004-$ linked to the School Grant. Notwithstanding, the increase in the time in school for the age eligible group in 2006 is impressive, especially through the enrolment index. In order to confirm if this change represents a discontinuity in the series, we plotted all the possible two-months periods in which a teenager could have been born so he/she was 16 years old in any moment of 2004 and 2006.

Figure 3 aggregates data for 2004 and 2006 for the 16 years old population. The '-1' and ' 1 ' represent the two-months anniversary periods in which the age eligibility rule for CCTs is the most relevant. Whereas the period ' 1 ' describes the teenagers whose anniversary was in the two months ending a calendar year, the period ' 1 ' presents teenagers whose anniversary was in the two months starting another calendar year. 
In 2006 there is a clear discontinuity between these two periods more exposed to the CCTs' age cut-off rule. On the other hand, in 2004 there is no such rupture, despite a positive trend of higher time in school as we go towards the teenagers eligible for the CCTs' benefit.

\section{FIGURE 3 TIME IN SCHOOL FOR TEENAGERS - COMPLETE AND INCOMPLETE 16 YEARS OF AGE AND INCOME ELIGIBLE TO CCTS (TWO-MONTHS ANNIVERSARY PERIODS)}

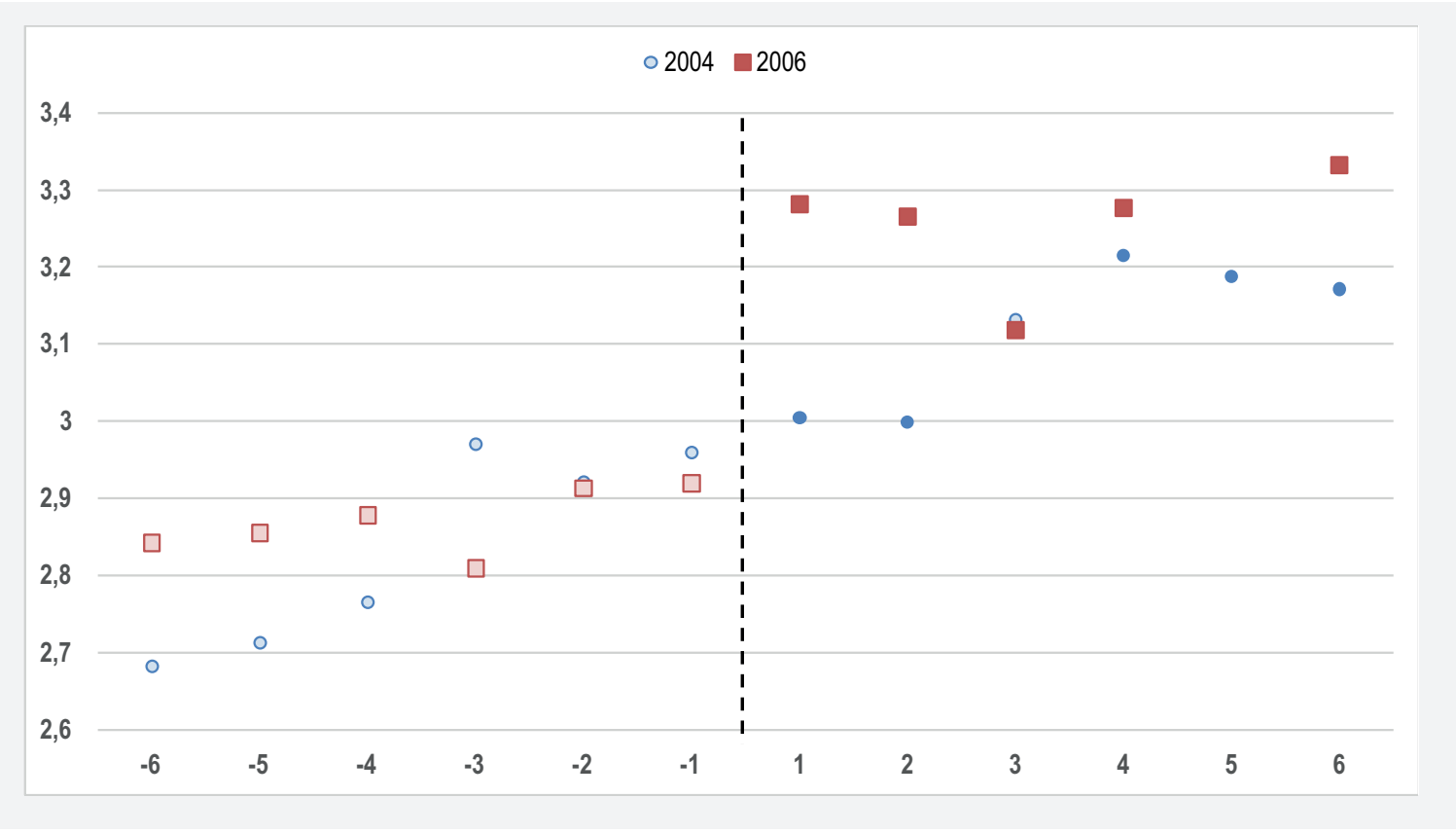

Source: Elaborated by the authors.

The aggregated data also revealed that the demand and demand 1 motives for abandoning school also reduced substantially when comparing the teenagers who completed 16 years in the first two months of 2004 and 2006 in relation to the ones who had completed in the last two months of 2003 and 2005 , respectively. In 2004, the relative fall in demand and demand 1 motives was of $13 \%$ in favour of the eligible group, while in 2006 the relative fall was even bigger, reaching $44 \%$. Therefore, differently from the children between 6 and 15 years old, the subjective data for the eligible 16 years-old teenagers by both age and income criteria suggest not only the validity of the income relief hypothesis in 2004, but also an increase in these effects in 2006.

In conclusion, the initial statistics suggest the BFP is not wrong in targeting its conditionalities at the population between 6 and 15 years old given the educational discrepancies observed for the group eligible in income terms for the programme. The data for this group also suggest increases in the time in school between 2004 and 2006 led by gains in enrolment and attendance indexes, both part of BFP's educational conditionalities. However, the motives given to dropout did not confirm the income alleviation hypothesis for the eligible group linked to CCTs programmes. Regarding the 16 years-old teenagers eligible in both age and income terms, the statistics suggest a positive impact 
of these programmes by showing an impressive increase in their time in school accompanied by a substantial fall in their motives for dropout linked to a lack of income.

\section{CCT AND TIME IN SCHOOL: IMPACT ANALYSIS BETWEEN 2004 AND 2006}

Table 2 presents the sign of the estimated coefficient of interest for each regression testing the hypothesis of the BFP's impact on SPI, its three components and the motives to abandoning school and not attending classes. We assessed the results for the group between 6 and 15 years old, subjected to the BFP's educational conditionalities, complementing the empirical evaluation with the analysis of the income eligible 16 years-old teenagers exposed to the age eligibility rule.

\section{TABLE 2 SIGN OF THE ESTIMATED COEFFICIENT OF INTEREST FOR THE ELIGIBLE GROUP}

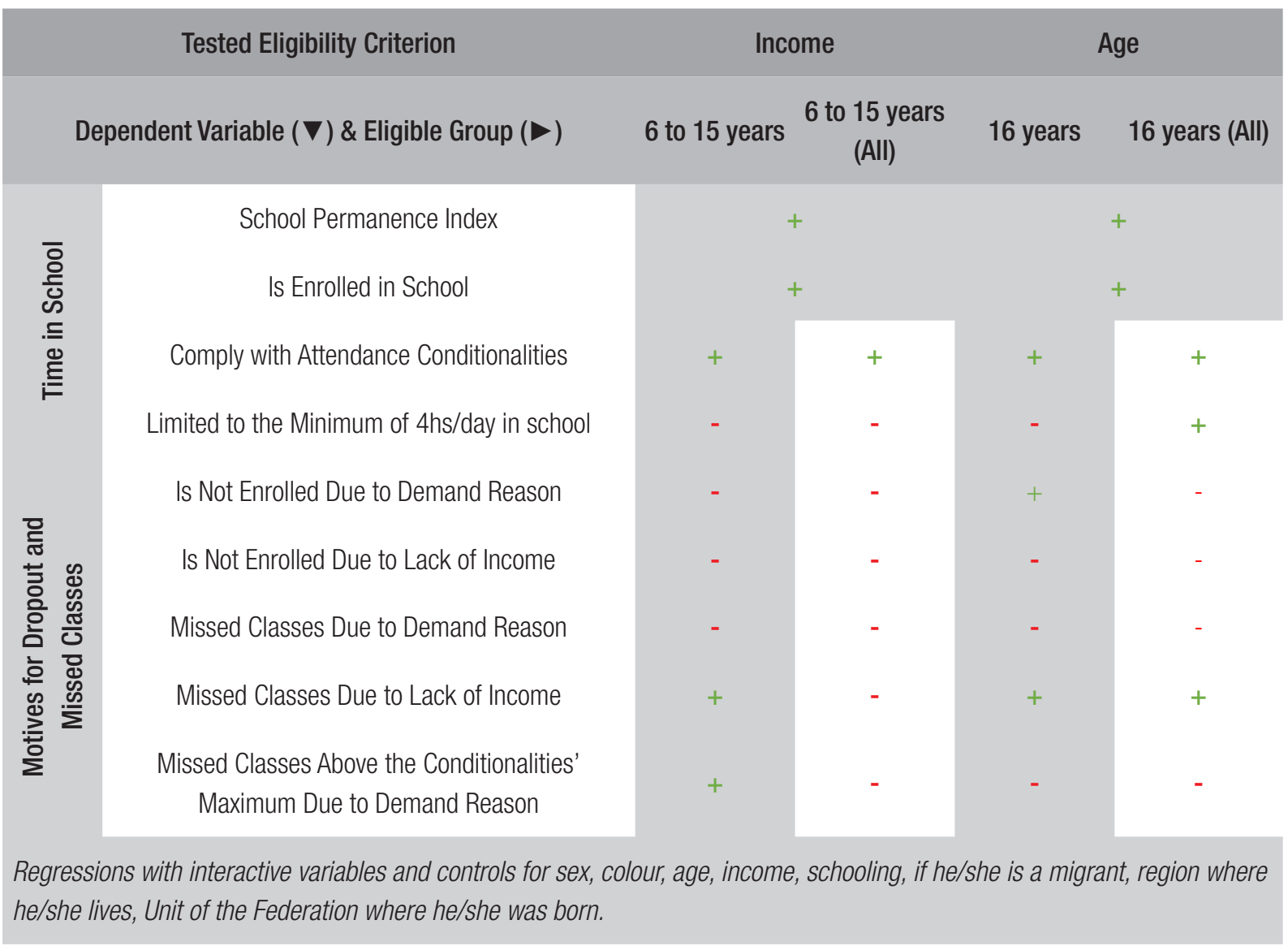

Source: Elaborated by the authors

We tested two regressions for each group, one without interactive variables and the other with a time interactive variable ('YEAR' - which assumes the value ' 1 ' in 2006 and ' 0 ' otherwise). In our attempt of disentangling the BFP's effects in the time in school, we first incorporated a sequential analysis of the partial impact observed on enrolment, attendance and school journey, respectively. 
Then, we evaluated the impacts on the total target population between 2004 and 2006 according to each component as well. For example, we studied the determinants behind the chances of an income eligible potential student between 6 and 15 years old is enrolled in school, and then assessed, among the enrolled students, the chances of complying with the BFP's conditionalities on attendance. Next, we estimated the total impact on the income eligible population between 6 and 15 years old, including those enrolled and not enrolled in school, in order to test if the results remain the same for the total target population. The idea behind this two-layer assessment is to first detect the magnitude of the programme's effects in each part of its educational conditionalities, and then answer the secondary question regarding the impacts observed on the target population as a whole.

The estimated coefficient of interest for the population between 6 and 15 years old is the one for the interactive variable combining the 'YEAR' variable and the 'Eligibility' dummy - which assumes the value ' 1 ' if the individual income net of government transfers is eligible for the BFP in the period. Regarding the 16 years-old teenagers, the estimated coefficient of interest is the one for the interactive variable combining the 'YEAR' variable and the variable for the anniversary in the two-months period immediately after the age cut-off rule (thus the first two months of 2004 and 2006), being the control group the ineligible population who completed 16 years in the last two months of 2003 and 2005.

The results obtained in the logistic regressions for the components of time in school are presented in Table 2. The results do not allow us to reject the hypothesis of BFP's causal impact on the eligible target population during the period of the programme's expansion. For the eligible children between 6 and 15 years old, in 2006, chances were 9\% higher to be enrolled in school, 22\% higher to meet the attendance conditionalities, and 5\% lower of being bounded to the minimum of four daily hours in school. This school journey represents the legal minimum journey length according to the Lei de Diretrizes e Bases (Law of Directives and Bases of National Education), thus suggesting an unexpected impact on the school journey for the eligible group in relation to the control group between the two years in the sample. At face value, this result suggests that BFP's beneficiaries had an extension in their school journey. By testing the results for attendance and school journey also including those potential students out of school, we observed that the eligible group maintained chances $17 \%$ higher to attend school according to the programme's rules, however the effect in school journey was neutralised.

TABLE 3 IMPACTS OF THE BOLSA FAMÍLIA ON THE COMPONENTS OF TIME IN SCHOOL - ODDS RATIO

\begin{tabular}{lcc} 
& Logistic Regression with Aggregated Data from 2004 and 2006 & Age \\
\hline Eligibility Criterion Tested & Income & 16 years \\
\hline Dependent Variable $(\nabla)$ \& Eligible Group $(\triangleright)$ & 6 to 15 years & $1.62^{\star *}$ \\
\hline Enrolled in School & $1.09^{\star \star}$ & $(0.0117)$ \\
\hline
\end{tabular}




\begin{tabular}{|c|c|c|}
\hline \multicolumn{3}{|c|}{ Logistic Regression with Aggregated Data from 2004 and 2006} \\
\hline Eligibility Criterion Tested & Income & Age \\
\hline Dependent Variable $(\boldsymbol{\nabla})$ \& Eligible Group $(\boldsymbol{)})$ & 6 to 15 years & 16 years \\
\hline \multirow{2}{*}{ Comply with Attendance Conditionalities } & $1.22^{\star *}$ & $1.08^{\star \star}$ \\
\hline & (0.0018) & (0.0162) \\
\hline \multirow{2}{*}{ Limited to the Minimum of $4 \mathrm{hs} /$ day in school } & $0.95^{\star *}$ & $0.94^{\star \star}$ \\
\hline & $(0.0012)$ & $(0.0128)$ \\
\hline \multicolumn{3}{|c|}{ ** statistically significative at the 95\% confidence level (estimate's standard error). } \\
\hline \multicolumn{3}{|c|}{$\begin{array}{l}\text { Regressions with interactive variables and controls for sex, colour, age, income, schooling, if he/she is a migrant, region } \\
\text { where he/she lives, Unit of the Federation where he/she was born. }\end{array}$} \\
\hline
\end{tabular}

Source: Elaborated by the authors.

Then, we restricted the sample to the individuals subjected to the BFP's age eligibility rule in order to incorporate the impacts observed through the age cut-off criterion. The results suggest that the eligible group who completed 16 years in the first two months of 2006 had chances $62 \%$ higher to be enrolled in school, $8 \%$ higher to meet the attendance conditionalities and a probability $6 \%$ higher of studying more than 4 hours per day in relation to the ineligible group who completed the same age in the last two months of the previous year. When we test attendance and school journey effects for the total population, the impact on attendance conditionalities becomes even stronger - going up to chances $51 \%$ higher of meeting the BFP's educational requirements, however, the impact on school journey was reversed - a probability $16 \%$ higher of being bounded to the minimum of four daily hours in school. In this case, we have to acknowledge the role of the potential students out of school in these results. Whereas the results in enrolment and attendance are always positive, school journey effects are not unanimously positive. Notwithstanding, despite the inexistence of impact on the total population, we observed an unexpected extension on the school journey's length for the two eligible groups. Since a technical assessment on the BFP's impacts must give primary attention to the enrolled group, given that this is a necessary condition for receiving the benefit (although not sufficient), we believe that the effects observed in the eligible population should receive priority in relation to the results for the total population targeted by the programme.

In order to test the hypothesis that the programme alleviates the demand issues alleged by the households eligible to the BFP, we tested logistic regressions on the motives for abandoning school and not attending classes. Even though the results are not unanimous, they do not allow us to reject the hypothesis that CCTs offer an income relief for the eligible population by reducing the demand motives given to dropout or miss classes.

For the population between 6 and 15 years old that is not enrolled in school, the group eligible to the BFP has $17 \%$ less chances of leaving school for demand motives, and among those who alleged demand motives to dropout, the eligible group has $4 \%$ less chances of abandoning school for demand 1 motives in this period. The tests using the total population not only confirm but also reinforce the previous results: the eligible group has $15 \%$ less chances of not being enrolled in both cases due to these reasons.

In turn, 16 years-old teenagers out of school and eligible in both income and age criteria to the BFP have chances $20 \%$ higher of abandoning school for demand motives, however, among those who 
alleged demand motives for leaving school, the eligible group has a probability $21 \%$ lower to dropout for demand 1 reasons. However, when testing for the total population, the eligible group has $30 \%$ and $41 \%$ less chances of dropping out alleging demand and demand 1 reasons, respectively.

By testing the specific hypothesis of leaving school because of labour motives, the results found for the group that is not enrolled in school by demand 1 motives suggest that eligible individuals between 6 and 15 years old have chances three times bigger to evade school for labour reasons, in relation to the non-eligible group, between 2004 and 2006. However, the regression test for the total population, including both enrolled and not enrolled potential students, presented an estimated coefficient that was not statistical significative, thus not allowing us to be certain about the higher chances of the eligible group dropping out to find a job. When we test for the 16 years-old teenagers, the eligible group has chances $63 \%$ and $43 \%$ lower to abandon school for labour reasons using either a sample made of teenagers out of school for demand 1 motives or the total population of 16 yearsold teenagers, respectively.

Since non-enrolment in school is a necessary and sufficient condition for losing the BFP's variable benefit, disregarding income or age, we must be careful in considering results from tests made using a sample of only people out of school. Even if one supposes a failure in the programme's conditionalities control and a share of the eligible potential students out of school actually receives the benefit, a technical assessment on the BFP's impact must give priority to a sample that covers the eligible group enrolled in school, once being in school is a condition for receiving the benefit. Therefore, given that the tests based on the total population suggest income reliefs effects coming from the programme, it is not possible to reject the hypothesis that the BFP reduces dropout motivated by demand issues for the eligible population. But what can we assert regarding the effects in school attendance?

The tests reveal that the eligible group between 6 and 15 years enrolled in school have chances $9 \%$ lower and 7\% higher of missing classes for demand and demand 1 reasons, respectively. In turn, eligible 16 years-old teenagers have $41 \%$ less chances of missing classes for demand reasons but almost four times more chances of missing classes for demand 1 reasons. Tests for the total population show that the probability of missing classes for demand and demand 1 reasons are $8 \%$ and $1 \%$ lower, respectively, for the eligible group between 6 and 15 years old, while the odds ratio for the eligible 16 years-old teenagers maintained the same direction.

Nevertheless, it is worth noting that these results encompass students from all the missed classes' spectrum, going from students who missed classes and still met the attendance conditionalities up to students who missed more classes than the maximum allowed by the programme. Therefore, more tests are needed in order to confirm the programme's impact. After testing for the total population using a regression on the possibilities of missing more than the limit of 5 classes for demand reasons, we observed chances $8 \%$ and $35 \%$ lower for the eligible group according to the income and age criterion, respectively. However, when we tested only using the sample of potential students out of school, the results are not clear since the income eligible group has chances $12 \%$ higher of missing more classes than the maximum allowed by the programme for demand reasons, while the age eligible group has chances $66 \%$ lower of not complying with the attendance conditionalities for demand reasons. A test that was not executed and could have contributed to this analysis is to test the chances of the eligible group to miss more classes than allowed by the BFP for demand 1 reasons, both for the sample of potential students who alleged demand motives for missing classes and the total population in the two eligible groups. 
be addressing an important leakage of the programme since we observed a substantial fall in the estimated chances of being enrolled in school for the 16 years-old group not eligible to the BFP. The reasons that were given by the potential students for not being in school also suggest the need for extending the benefit for adolescents.

In order to corroborate the impacts on time in school, we tested an ordered multinomial model divided in five SPI's categories, being the first made of potential students out of school, thus, with SPI equal to zero; and the last made of potential students with SPI between 0.75 and 1 . All the estimated results were statistically significative. The estimated coefficients for the variable of interest in the model with and without interactive variables are disposed in Table 5 below, which also presents the standard errors and the p-value.

The results for the population between 6 and 15 years old in the model without interactive variables show that the income eligible group has lower time in school when compared to ineligible group. These findings are static and only suggest that the most vulnerable group (the income eligible) has worst results in terms of their permanence in school. In turn, the interactive regression reveals that the eligible group has higher time in school than the ineligible group between 2004 and 2006, therefore aligned with the previous results obtained in the binomial models for each component of the time in school. For the 16 years-old eligible group, the results show that the age eligible group not only has more time in school than the non-eligible in the static model, but this difference increased in the period analysed. Consequently the multinomial model confirms the hypothesis of CCTs' causal impact on the time in school with an increase in the conditionalities' dosage-effects between 2004 and 2006.

TABLE 5 IMPACTS OF THE BOLSA FAMÍLIA ON THE TIME IN SCHOOL

\begin{tabular}{|c|c|c|c|c|}
\hline \multicolumn{5}{|c|}{ Ordered Multinomial Model - Logistic Regression with Aggregated Data from 2004 and 2006} \\
\hline Tested Eligibility Criterion & \multicolumn{2}{|c|}{ Income } & \multicolumn{2}{|c|}{ Age } \\
\hline \multirow[b]{2}{*}{ Dependent Variable $(\boldsymbol{\nabla})$ \& Eligible Group $(\boldsymbol{})$} & \multicolumn{2}{|c|}{6 to 15 years (All) } & \multicolumn{2}{|c|}{16 years (All) } \\
\hline & $\begin{array}{l}\text { Withouth } \\
\text { Interactive } \\
\text { Variables }\end{array}$ & $\begin{array}{l}\text { With Interactive } \\
\text { Variables }\end{array}$ & $\begin{array}{c}\text { Withouth } \\
\text { Interactive } \\
\text { Variables }\end{array}$ & $\begin{array}{c}\text { With Interactive } \\
\text { Variables }\end{array}$ \\
\hline Time in School (SPI) & $\begin{array}{l}-0.13^{\star \star \star} \\
(0.0137)\end{array}$ & $\begin{array}{c}0.07^{\star \star} \\
(0.0228)\end{array}$ & $\begin{array}{l}0.19^{\star \star} \\
(0.0959)\end{array}$ & $\begin{array}{c}0.33^{*} \\
(0.1963)\end{array}$ \\
\hline $\begin{array}{l}{ }^{* *} \text { statistically significant at the } 99 \% \text { confidence le } \\
\text { significant at the } 90 \% \text { confidence level. } \\
\text { Regressions with controls for sex, colour, age, incon } \\
\text { Federation where he/she was born. }\end{array}$ & atistically sigr & $\begin{array}{l}\text { cant at the } 95 \% \text { c } \\
\text { s a migrant, regio }\end{array}$ & whidence leve & $\begin{array}{l}\text { * statistically } \\
\text { lives, Unit of the }\end{array}$ \\
\hline
\end{tabular}

Source: Elaborated by the authors.

Finally, we test how the inequality in the distribution of the time in school and its three components changed in the period within each group of interest in the analysis. Here, the idea is to observe if the poorest and most vulnerable people were indeed the main beneficiaries in terms of time in school 
during the BFP's expansion, comparing the results with the observed advancements in education that concomitantly happened in Brazil during this period. Table 6 shows the mean value of the Theil-T coefficient and Gini coefficient in 2006 for the time in school and its three components, besides the observed variation between 2004 and 2006 in these indicators for (i) Brazil; (ii) the group between 6 and 15 years old; and (iii) both groups of 16 years-old teenagers, those who completed 16 years in the first two months of 2006 and the adolescents who completed the same age in the last two months of 2005. For all cases analysed here, the closer to 0 is the indicator, the better distributed is the variable of interest.

TABLE 6 TIME IN SCHOOL INEQUALITY

\begin{tabular}{|c|c|c|c|c|c|c|c|c|c|}
\hline \multicolumn{10}{|c|}{ Data for the Total Population in 2004 and 2006} \\
\hline \multirow{2}{*}{\multicolumn{2}{|c|}{ Dependent Variable \& Eligible Group }} & \multicolumn{2}{|c|}{ Time in School } & \multicolumn{2}{|c|}{ Enrolment Index } & \multicolumn{2}{|c|}{ Attendance Index } & \multicolumn{2}{|c|}{ School Journey Index } \\
\hline & & Theil-T & Gini & Theil-T & Gini & Theil-T & Gini & Theil-T & Gini \\
\hline \multirow{2}{*}{$\begin{array}{l}\text { Brazil ( } 0 \text { to } \\
17 \text { years) }\end{array}$} & Level in 2006 & 0.294 & 0.311 & 0.277 & 0.242 & 0.016 & 0.268 & 0.033 & 0.297 \\
\hline & $\begin{array}{l}\text { Variation (\%) } \\
2004-2006\end{array}$ & $-9.46 \%$ & $-6.82 \%$ & $-8.86 \%$ & $-7.68 \%$ & $-31.73 \%$ & $-9.34 \%$ & $-10.71 \%$ & $-4.92 \%$ \\
\hline \multirow[b]{2}{*}{6 to 15 years } & Mean in 2006 & 0.052 & 0.117 & 0.038 & 0.037 & 0.006 & 0.068 & 0.013 & 0.099 \\
\hline & $\begin{array}{l}\text { Variation (\%) } \\
2004-2006\end{array}$ & $-20.10 \%$ & $-10.82 \%$ & $-19.76 \%$ & $-19.37 \%$ & $-45.27 \%$ & $-21.93 \%$ & $-3.20 \%$ & $-4.38 \%$ \\
\hline \multirow{2}{*}{$\begin{array}{l}16 \text { years } \\
\text { (Age Eligible) }\end{array}$} & Mean in 2006 & 0.210 & 0.251 & 0.193 & 0.176 & 0.015 & 0.207 & 0.024 & 0.231 \\
\hline & $\begin{array}{l}\text { Variation (\%) } \\
2004-2006\end{array}$ & $-7.04 \%$ & $-6.47 \%$ & $-3.80 \%$ & $-3.44 \%$ & $-49.73 \%$ & $-11.46 \%$ & $-8.13 \%$ & $-0.64 \%$ \\
\hline \multirow{2}{*}{$\begin{array}{l}16 \text { years (Age } \\
\text { Ineligible) }\end{array}$} & Mean in 2006 & 0.260 & 0.289 & 0.242 & 0.215 & 0.017 & 0.246 & 0.027 & 0.269 \\
\hline & $\begin{array}{l}\text { Variation (\%) } \\
2004-2006\end{array}$ & $3.96 \%$ & $1.52 \%$ & $7.05 \%$ & $6.23 \%$ & $-32.38 \%$ & $-0.07 \%$ & $-4.28 \%$ & $5.50 \%$ \\
\hline
\end{tabular}

Source: Elaborated by the authors.

The results reveal a marked fall in inequality in all indicators tested at the nation scale, with the strongest effect observed for the population targeted by BFP's conditionalities. For the teenagers eligible to the BFP the results also show a fall in inequality in indicators related to time in school, despite in a lower magnitude. For the teenagers ineligible the results are the opposite: an increase in inequality for almost all indexes in the period.

It is worth noting that the bulk of the fall in the time in school inequality for the two eligible groups (by income and age, respectively) happened in enrolment and attendance, while the distribution in school journey was less affected. These results are aligned to the hypotheses of impact from the CCTs' conditionalities, once school journey is not a educational conditionality. Moreover, if previously 
estimated results suggested a small increase in the school journey for the BFP's beneficiaries, the inequality tests revealed that these effects were negligible regarding inequality reduction.

\section{CONCLUSION}

This article assessed children's time in school, here understood as the average daily hours spent by a potential student in school, through an indicator made of three components: an enrolment index; an attendance index; and an school journey index. By analysing in an aggregated manner different aspects of the relationship between the Bolsa Familia Programme and education, the article focused on measuring time in school based on the available information of the PNAD's special supplements. The article includes the different educational conditionalities, the connexion between supply and demand elements, and the motives given by the potential student. We explored two identification hypotheses to assess the programme's impact using (a) the BFP's expansion, and (b) the discontinuity in the age eligibility rule.

The objective and subjective results do not allow us to reject the hypothesis of the BFP's causal impact on the time in school of its eligible population between 2004 and 2006. At the end of the period, the eligible group between 6 and 15 years old had chances $9 \%$ and 22\% higher of complying with the BFP's conditionalities on enrolment and attendance in school, respectively, besides chances $6 \%$ higher of being exposed to a school journey superior than the minimum by law. For the 16 yearsold eligible teenagers the chances were $62 \%, 8 \%$ and $6 \%$ higher, respectively. These positive impacts were confirmed by a multinomial model.

For the eligible population, the results also suggest a reduction in the chances of abandoning school and missing classes linked to demand reasons, thus not allowing us to reject the hypothesis of income relief for the BFP's eligible group linked to the benefit offered by the programme.

Finally, we observed a marked fall in the time in school inequality for the population targeted by the programme, especially in the enrolment and attendance indexes, which are both directly affected by the educational conditionalities of the programme. However, the estimated results showed that the level and distribution of the school journey for the eligible population were marginally affected in this period, turning this component into a barrier for new gains in time in school. Consequently, educational policies should focus on raising the school journey. Finally, it is of fundamental importance to coordinate 'means' incentives (such as the reading time in the classroom) and 'ends' incentives (such as offering cash payments for higher marks) in order to reinforce a strategic coordination of the agents involved in the Brazilian education (students, parents and teachers) and their interests (Fryer, 2010, 2012; Neri, 2017). 


\section{REFERENCES}

Campello, T., \& Neri, M. (Orgs.). (2013). Programa Bolsa Família: uma década de inclusão e cidadania. Brasília, DF: Instituto de Pesquisa Econômica Aplicada, Chapters 1 (Campello); 2 (Paiva, Falcão \& Bertholo); 6 (Craveiro \& Ximenes); 8 (Souza \& Osorio); 18 (Oliveira \& Soares); 19 (Cereno, Silva \& Proença); 20 (Silveira, Campolina \& Horn); 21 (Barbosa e Corseuil); 22 (Oliveira \& Soares) and 23 (Rêgo \& Pinzani).

Cardoso, E., \& Souza, A. P. (2004). The impact of cash transfers on child labor and school attendance in Brazil (Working Paper No. 04-W07). Nashville, TN: Vanderbilt University.

Fryer, R. G., Jr. (2010, April). Financial incentives and student achievement: evidence from randomized trials (NBER Working Paper No. 15898). Cambridge, MA: Harvard University.

Fryer, R. G., Jr. (2012, January). Aligning student, parent and teacher incentives: evidence from houston public schools (NBER Working Paper No. 17752). Cambridge, MA: Harvard University.

Hanlon, J., Barrientos, A., \& Hulme, D. (2010). Just give money to the poor: the development revolution from the Global South. Sterling, VA: Kumarian.

Kakwani, N., Neri, M., \& Son, H. (2010). Linkages between pro-poor growth, social programs and the labor market: the recent Brazilian experience. World Development.
Molyneux, M., Jones, N., \& Samuels, F. (2016). Can cash transfer programmes have "transformative" effects? The Journal of Development Studies, 52(8), 1087-1098.

Neri, M. (2009a). O paradoxo da evasão e as motivações dos sem escola. In F. Veloso, S. Pessoa, R. Henriques, \& F. Giambiagi (Orgs.), Educação básica no Brasil: construindo o país do futuro (pp. $\mathrm{x}-\mathrm{y}$ ). Rio de Janeiro, RJ: Elsevier.

Neri, M. (2009b). O tempo de permanência na escola $e$ as motivações dos sem-escola. Rio de Janeiro, RJ: Fundação Getulio Vargas.

Neri, M. (2017). Uma próxima geração de programas de transferência de renda condicionada. Revista de Administração Pública, 51(2), 168-181.

Oliveira, J. (2008). Custo-efetividade de políticas de redução do tamanho da classe e ampliação da jornada escolar: uma aplicação de estimadores de matching (Master Thesis). São Paulo, SP: Universidade de São Paulo.

Pedrozo, E. (2010). Efeitos de elegibilidade e condicionalidade do Programa Bolsa Família sobre a alocação de tempo dos membros do domicílio (Doctoral Dissertation). São Paulo, SP: Fundação Getulio Vargas.

Sawyer, D. O. (2007). Sumário executivo: avaliação de impacto do Programa Bolsa Família. Brasília, DF: Ministro do Desenvolvimento Social e Combate à Fome.

\section{Marcelo Neri}

https://orcid.org/0000-0002-5911-6951

$\mathrm{PhD}$ in Economics at Princeton University; Diretor of FGV Social and Professor at the Brazilian School of Economics and Finance - Getulio Vargas Foundation (FGV EPGE). E-mail: marcelo.neri@fgv.br

\section{Manuel Camillo Osorio}

https://orcid.org/0000-0003-1856-9310

MSc Political Economy of Late Development at the London School of Economics; BA in Economics at Pontifical Catholic University of Rio de Janeiro (PUC-Rio); Researcher at Getulio Vargas Foundation (FGV Social). E-mail: mcamillo21@gmail.com 